\title{
The Importance of Customer Loyalty Programs for the European Airline Industry
}

\author{
Mark Wever \\ University of Latvia, Riga, Latvia
}

\begin{abstract}
In order to survive in a highly competitive market like that of airlines industries, it is essential to win over customers' long-time loyalty. Despite the market for airline industries seems to be borderless because they offer worldwide flights, it is a small one, caused in a comparative competition. On one hand, the airlines are faced with cost reduction to be competitive and on the other; they have to build attractive offers for their customers. Therefore, they created customer loyalty programs, which should ensure a winning over the customers. Especially, the European airline industry is facing cost reduction programmes, but in contrast, they have to develop attractive offers for their customers. To achieve a winning over their customers, airlines face creating loyalty programmes in a market where simply all competitors do the same. What can airlines do to win additional customers or entice customers away from their competitors? This study deals with the topic of customers' loyalty programmes in the European airline-industry and their importance for both airlines and customers.
\end{abstract}

Keywords: airlines, customer loyalty, importance, Europe

Markets and consumer expectations are changing in a dynamic way and the global airline industry grows continuously and rapidly, too (Strategy\&, 2015). Robust and consistent profitability is elusive and the industries revenue has doubled in the past decade from US\$ 369 billion in 2004 to a projected amount of US\$ 746 billion in 2014 (Strategy\&, 2015). Low-cost carriers (LCCs) now control 25\% of the worldwide market, although the profit margins of airlines "are razor thin, less than 3\% overall” (Strategy\&, 2015). To manage the growing pressure of reduced costs and improved operational efficiency, airlines have two options: They can upgrade their hard products, namely their aircraft-fleet or they can enhance the soft product, which is associated with "seamless customer experience across all aspects of air travel from reservation to touchdown" (Strategy\&, 2015). Renewing and/or updating their fleet is an expensive way and the payback could be long in coming, whereas the soft product update which offers new comfort in travelling is to manage with reduced costs. However, such enhancements entail a change in wholesale behaviour and a cultural shift within the organisation (Strategy\&, 2015). In response to these trends, the following specific measures have to take place to remain competitive (Strategy\&, 2015):

(1) Getting to know customers better;

(2) Use digitization to reduce operating costs;

Corresponding author: Mark Wever, doctoral studies programme in management, modul global management and leadership, promotional exam in administration and management, head of internal sales department and customer service at Walter Stauffenberg GmbH \& Co. KG, Werdohl, Germany, Faculty of Economics and Management, University of Latvia; research field: management science. 
(3) "Cut the fat, not the muscle";

(4) Collaborate strategically (Strategy\&, 2015).

Today's customers are faced with frustrations by air travelling. Figure 1 shows the travellers' expectations and their frustrations.

Figure 1 shows the difference between the customer's expectation and the frustration he/she has to accept in reality. Furthermore, possible solutions are being presented, e.g., $47 \%$ of passengers are frustrated through security controls and customs, which could be avoided by management systems to track flows of people passing security and border control (Amadeus, 2012). Most of the recommendations could be solved fast and cost effective, but also require organisational rethinking and new strategies. The figure below shows the actual trends of travel consumer's wishes. The next step shows anticipated future changes, where new traveller types occur.

Amadeus has anticipated six new traveller "tribes", as shown in Figure 2: These are the "obligation meeter", the "simplicity searcher", the "reward hunter", the "ethical traveller", the "cultural purist", and the "social capital seeker" (Amadeus, 2012). The new traveller tribes are described as follows:

(1) Simplicity searcher (Amadeus, 2015). This type of persons lacks time and seeks relaxation, and, he/she is happy when people arrange and manage all their travel issues. He/she prefers to get simple information in clear formats. The growth of this group is based on the growing middle class in emerging markets. He/she is willing to share data when the results give them a hassle-free experience. The "simplicity searcher" is eager to receive bundled travel offers and packages including assurance and comfort;

(2) Reward hunter (Amadeus, 2015). He/she sees travel as a well-deserved treat and desires self-centred activities, like experiences focusing on self-indulgence, e.g., helicopter rides or visiting exotic mountaintops. The reward hunter is a data-driven person who is searching for a balance between comfort and efficiency. This consumer tribe prefers to purchase VIP (Very Important Person) treatment and bypass traditional check-in procedures. Furthermore, he/she is open to wellness or personal health offers;

(3) Social capital seeker (Amadeus, 2015). His/her gain is to share travel experiences at every opportunity via social networks and prefers "peer validated travel decisions". He/she is also monitoring own media presence and is a hopper in travel brands of airlines and agencies, furthermore, the social capital seeker is "open to heavy personal service providing like cabin options, hotel rooms, entertainment, and experience” (Amadeus, 2015);

(4) Cultural purist (Amadeus, 2015). He/she travels as an opportunity to develop unfamiliar cultures found off track and enjoys a break with a genuine life experience. His/her inspiration comes from word-of-mouth and from social networks. Cultural purists are open for the sharing economy and not determined by price, he/she is focussing on the experience. He/she values the impulsiveness and adventurousness of his/her travel and he/she is not keen on personalised services;

(5) Ethical traveller (Amadeus, 2015). The ethical traveller makes his/her travel decision with concession to his/her conscience, namely, he/she chooses a destination to boost the tourism there. The ethical traveller also focuses on eco-friendly offers in combination with ethical practices. He/she virtually tends to visit places that are otherwise inaccessible on ethical or political grounds. He/she might contribute, e.g., to local infrastructure or to school for ethical reasons. He/she tries to minimise the carbon footprint and is willing to make compromises towards environmental friendliness;

(6) Obligation meeter (Amadeus, 2015). He/she wants to achieve something special, such as attending a conference, or meeting a client. He/she books flights with minimum options and demands for a seamless switch between expense accounts and personal accounts. 


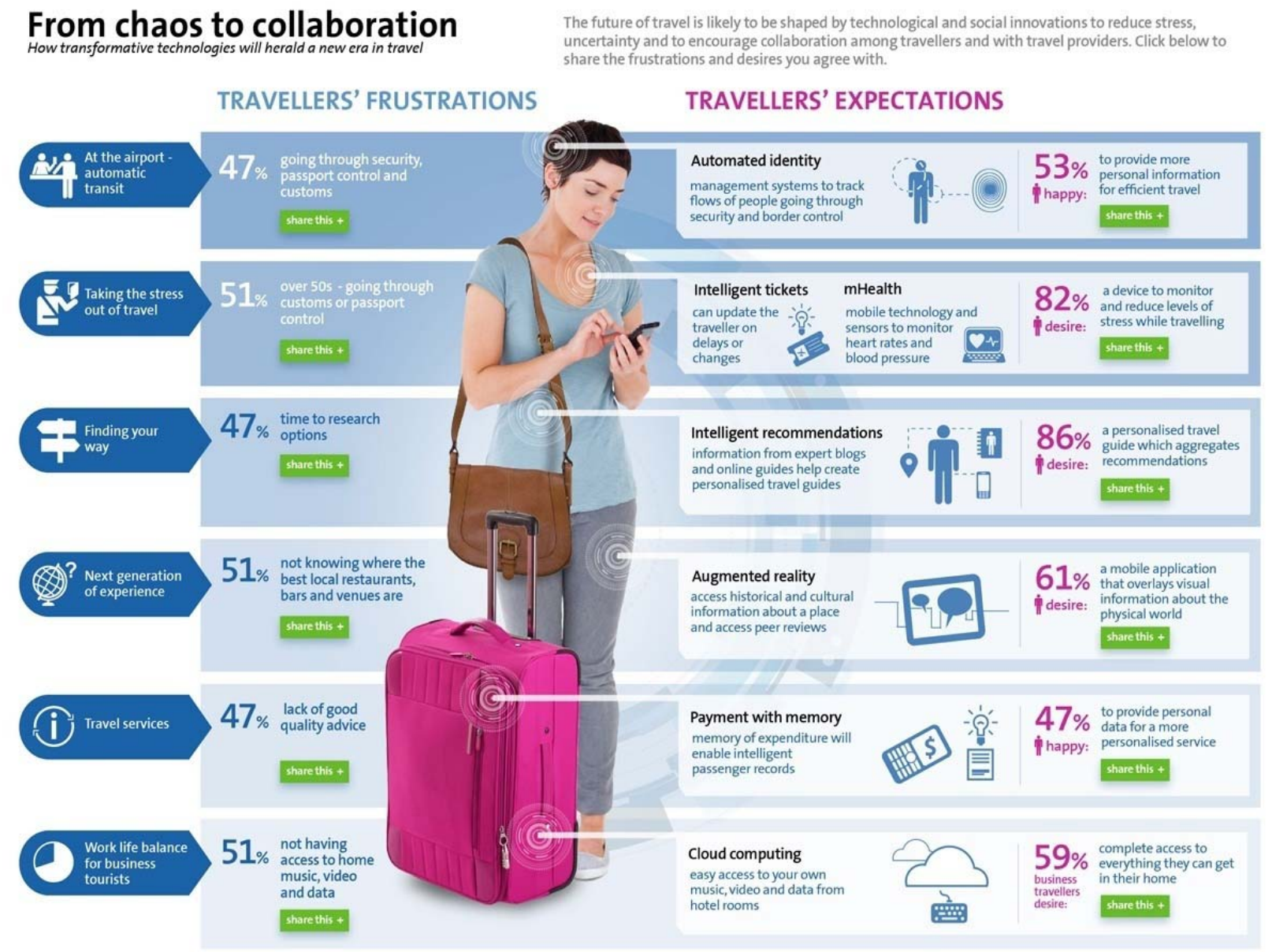

Figure 1. From chaos to collaboration ${ }^{1}$.

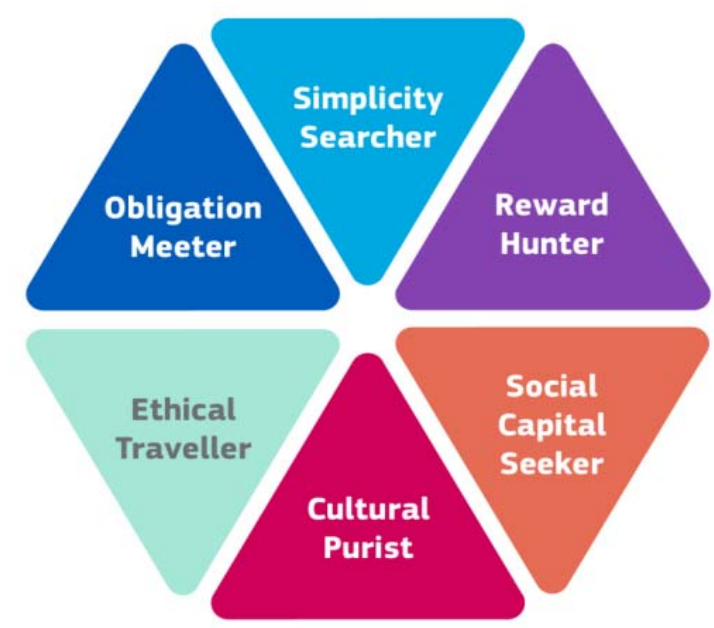

Figure 2. Traveller types—-2030².

\footnotetext{
${ }^{1}$ Retrieved from http://www.amadeus.com/web/binaries/1333089277310/ blobheader=image/png.

2 Amadeus. (2015). Future traveller tribes 2030: Understanding tomorrow's traveller. Retrieved from http://www.amadeus. com/documents/future-traveller-tribes-2030/travel-infographic-future-traveller-tribes-2030.png.
} 
The simplicity searcher books his flights a long time in advance. He/she tends to be a regular traveller who is used to spending his/her time at airports and appreciates entertainment while in transit. He/she focuses on the main objective but is willing to accept clever offers, which gives him/her an additional leisure experience.

\section{The European Airline Industry and the Importance of Loyalty Programmes}

As all other industries, the airline industry is under pressure to grow and to achieve financial profits, both requires lowering costs and strain to achieve high market-prices. The markets are saturated and to win new customers and to persuade them into a long-time relationship is essential. The costs of customer acquisition compared with the costs of keeping existing customer reveals, that gaining new customers is 4-10 times more expensive (The Chartered Institute of Marketing, 2015). "Statistically speaking, the costs of acquiring a new customer are 5-10 times more than retaining an existing one. Not only that, but repeat customers spend, on average, 67\% more" (Huthwaite International, 2015). Johnston, a member of the Chartered Institute of Marketing stated: "Research shows that it can cost up to 30 times as much to get a new customer as it does to keep an existing one. It pays to stay very close to your customers, so you know their exact needs, today and tomorrow" (The Chartered Institute of Marketing, 2015). To avoid expensive acquisition and strenuous competition is more comfortable and less expensive as a long time relationship with existing customers. Therefore, to ensure to win over the customers, the airline industry has created various loyalty programmes. There are a number of customer loyalty programmes on the market, which means great competition among airlines in creating successful packages in order to satisfy their customers. An American study revealed that only $25 \%$ of business travellers and $20 \%$ of leisure travellers limit their search to their preferred airline (Wessels, 2006). Still, if a frequent flyer programme exists, consumer loyalty rises by up to $80 \%$. Other factors of choosing an airline are the price, the professionalism of airline personnel, the ability to change or cancel itineraries without paying cancellation penalty, and the efficiency of security checks. In addition to that, the airport location, the seat and legroom size on the plane, the loyalty programme, the ability to upgrade, and the quality of meals are considered (Wessels, 2006). This study deals with the topic of customers loyalty programmes of the European airlines industry and their importance for airlines and customers. Customer retention such as client card systems increased sales up to $25 \%$ through payback cards. According to Ranzinger (2011), companies can achieve similar results with the right measure for customer retention, if it is strategically aligned and correctly researched as well as positioned appropriately for the requirements of the market (Ranzinger, 2011). The goal of this paper is to establish a preference list based on surveys, online research, and literature reviews, as well as on journals and comments (considering the keywords evaluation and comments). The following list will illustrate the degree and relevance of the effects of customer retention.

\section{Research Questions/Hypothesis}

The current market situation in the airline industry based on pressure on the competitors and the customer's expectations lead to the following research questions.

The central research question:

Which factors are essential to win customers for airline loyalty programmes?

The central research question induces the research hypothesis:

There are factors to win and keep important customers in a long-term relationship and keep them from leaving. 
The following chapter presents the research methodology.

\section{Methodology}

\section{Literature Review}

Literature review is already finished and the results are presented in Chapter 2 of this report.

\section{Empirical Part}

The empirical part is still in progress and there are no available results at this time.

\section{Online Research on Airline Portals}

Focussing on how loyalty programmes are offered, what benefits customers get and how the programmes are presented. In this online research design, wording and content are mentioned.

Online research. The efficiency of loyalty programmes is analysed by airline's balance sheets and business reports, to get factors of business success.

Online survey. Based on the theoretical framework for interviews and questionnaires, an online survey reveals what customers really want now and in future.

Planned content. The methodology comprises of five main chapters:

Introduction includes research questions, hypothesis, and methodology.

Theory 1 in Chapter 2 includes definitions of marketing, sales, controlling, accounting, and leadership, followed by a review of the relevant literature and a short summary at the end.

Theory 2 includes airlines and loyalty programmes that are discussed in chapter three.

Empirical research. As demonstrated in Figure 3, the empirical research contains of an online research focussing on airline bonus-programmes of the European airline industries, an economic research revealing factors of airline's success with loyalty programmes and an online survey which deals with the customer wishes for now and in the future.

Within an online survey, where the customer's wants and needs now and in future are analysed.

In the fifth chapter, the acknowledgements of the study are depicted. They will include implications for managers, limitations of the study, and future prospects with proposals for further research.

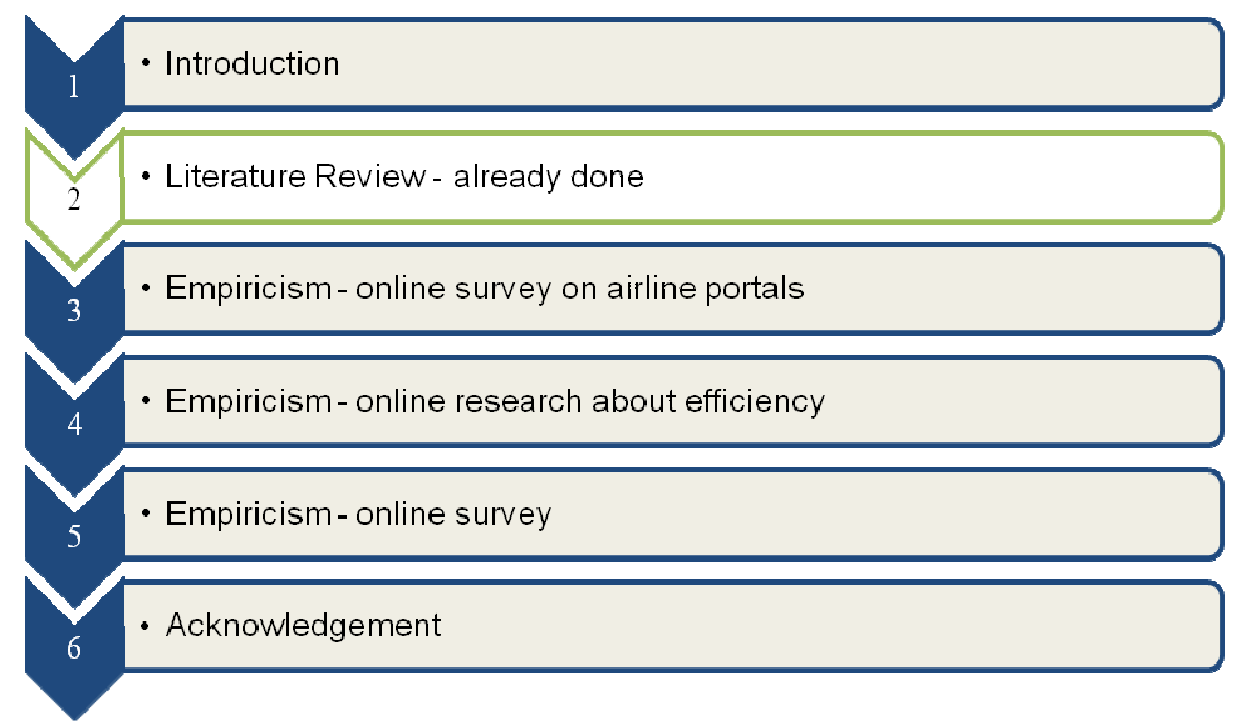

Figure 3. Research methodology. Source: The author's own illustration. 


\section{Conceptual Design}

As demonstrated in Figure 4: Conceptual design, the conceptual design of the study comprises primary and secondary research.

The theoretical part revealed the determining factors and economic frames of the airline business and loyalty programmes.

The empiricism comprises three parts:

(1) An online research to reveal efficiency factors of airline loyalty programmes;

(2) Further research to check the airline programmes status and the presentation to the customer;

(3) The third part is an online survey to get the customers' wish and needs now and in future.

Moreover, the results of the online research, about current customer loyalty programmes are compared with the customers' wishes and prospects to find out future gaps.

Although, the results of the literature review and the online research about efficiency factors are proved, about feasibility of the customers' needs and wants.

Finally, the future oriented and efficient factors of customer loyalty programmes are presented.

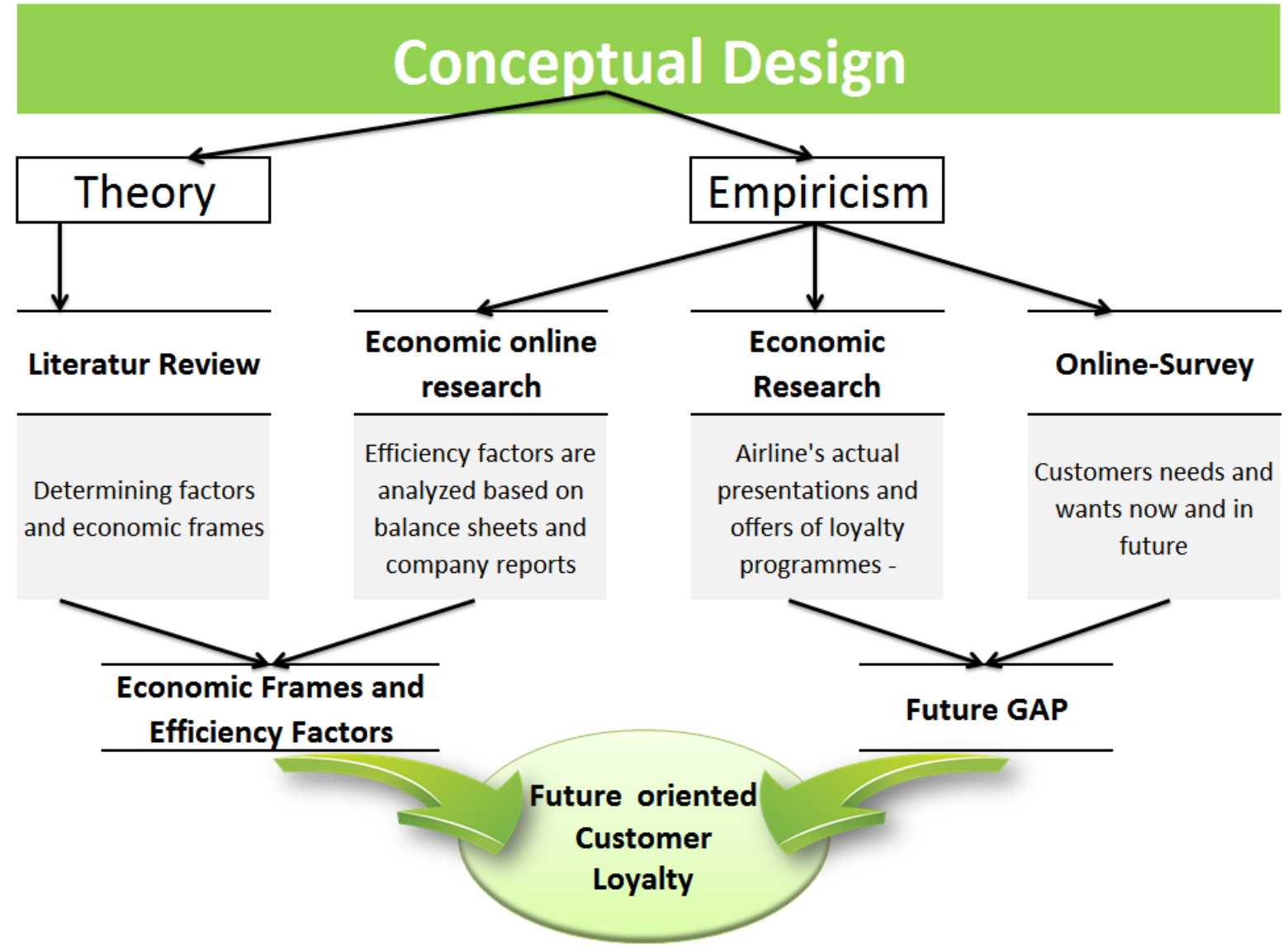

Figure 4. Conceptual design. Source: The author's own illustration.

\section{Interim Results}

As the study is in an ongoing process and the empiric research is not finished, the interim results are limited to literature review acknowledgement. 
The common and current literature of airlines and loyalty programmes were analysed for the purpose to examine the main drivers for loyalty programmes in the airline industry.

\section{Main Drivers of Loyalty Programmes}

In Table 1 the arguments extracted from literature are stated in alphabetical order:

Table 1

Extracted Main Drivers of Loyalty Programmes

Aircraft size and flight frequency

Analysing key success factors

Building alliances and co-operations

Building multi-hub networks

Changes in productivity and efficiency

Changing marketing strategies

Changing the network management

Competitive advantages

Disruption models

Eliminating cost drivers

Enhancement of customer orientation

Evolution of frequent flyer programmes

Fuel hedging strategies

Full or reduced board service

Future prospects

Global pressure of economic crisis

Implementing CSR (Corporate Social Responsibility)

Improving baggage tracking

Improving organisational resilience and crisis management

Improving performance

Internet penetration

Maximising revenue

Measuring and improving customer loyalty

Measuring customer expectations

Pressures of competitions and regulations

Price or non-price competition

Resisting turbulences and restrictions

Risk management

Service marketing

Service quality

Structural changes of organisations

Wage determinations

However, the missing puzzle pieces in this list are the changes in the consumers' behaviour and the anticipation of new traveller types. Renewing the aircraft fleet is an investment in hardware, which produces high costs, and it takes a long time to amortise, whereas customer loyalty programmes are cheaper. The analysis of key factors shows that to win over the customer is essential. In their study "What's Wrong With the Airline Industry? Diagnosis and Possible Cures”, Morrison and Winston stated which actors are problematic for airlines' losses of revenue (Morrison \& Winston, 2005). One of the main cost factors is, as mentioned in the 
introduction, the winning over of new customers. Other cost factors are "hard facts", like upgrading the airline fleet or reviewing the airlines' hardware. According to a US study, airlines generated a loss of \$13 with each passenger between 2001 and 2004 (Morrison \& Winston, 2005).

Substantial cost drivers are high fare prices, fuel consumption and fuel prices, labour and the competitive environment like the rising costs for hubs, and those for frequent flyer programmes (Ciliberto \& Williams, 2010).

\section{Service Strategies}

Two competing business models are common in the airline industries:

The FSA (Full-Service strategy), or also called full-service strategy and LFA (reduced service strategy) the strategy based on reduced services. Both models are compared in the following Figure 5.

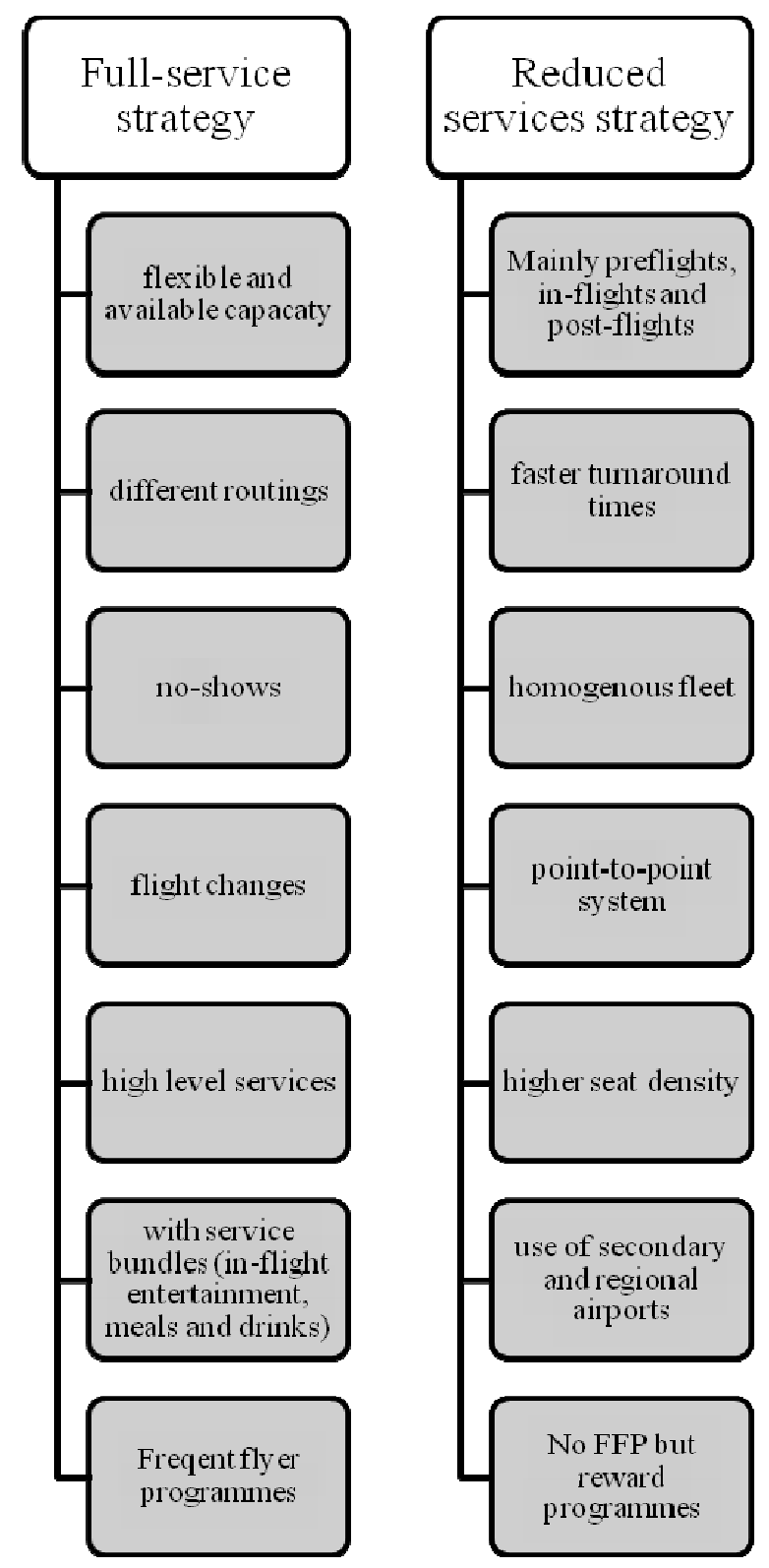

Figure 5. Full-Service strategy (FSA) vs. reduced service strategy (LFA). Source: The author's own representation. 


\section{Customer Expectations}

The deep understanding of the market place and the knowledge of customers' needs, wants, and demands is the basis to serve services and products, which conform to the customers' expectations (Kotler \& Armstrong, 2012).

Customer satisfaction depends on the product's perceived performance relative to a buyer's expectation. If the product's performance falls short of expectations, the customer is dissatisfied. If performance matches expectations, the customer is satisfied. If performance exceeds expectations, the customer is highly satisfied or delighted. (Kotler \& Armstrong, 2012)

Therefore, the offering to customers should shift from bundled to unbundled to give them the feeling of an "a la carte" sale (Birdsong, 2015). This could help to diminish the difference between the airliners offers and the customer satisfaction experience: The airline industry ranks at the bottom of customer satisfaction, with about $4 \%$, whereas $81 \%$ of airline executives believe that, it has significantly increased. In contrast to that, $66 \%$ of customers believe that customer satisfaction has been stable or decreased (Birdsong, 2015). For the customer lifetime, value is an essential part of the loyalty puzzle. The relationship between customers and airlines has to improve enormously. The money a customer spends on purchases from an airline over lifetime is called the lifetime value. Losing a customer is not losing one single sale (Kotler \& Armstrong, 2012). One of the main strategic marketing tools concerning customer loyalty is the effect of relationship-oriented promotion, which is supported by Pi and Huang, because they state that it "has significantly positive effects on satisfaction and trust" (Pi \& Huang, 2011).

\section{Alliances and Cooperation}

Alliances are cooperation agreements by which airlines integrate their networks and services and operate as if they were a single entity (but without the implied irreversibility of a concentration) while retaining their corporate identities (as in particular strategic alliances) and which are caught either by Article 81(1) EV and/or Article 53(1) of the EEA-Agreement or by the corresponding provisions in the competition laws of one or more of the national states. (European Competition Authorities [ECA] Air Traffic Working Group, 2004)

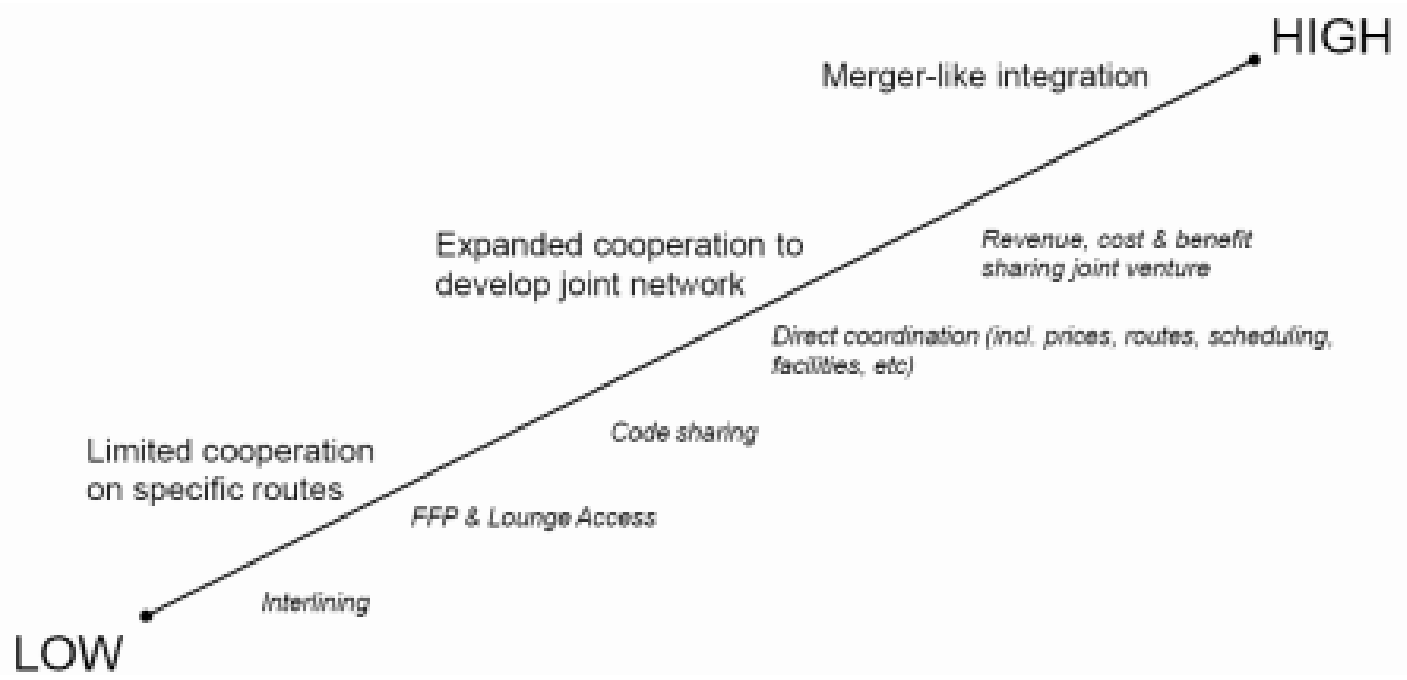

Figure 6. The spectrum of airline co-operation ${ }^{3}$.

Figure 6 shows the spectrum of airline co-operation.

\footnotetext{
${ }^{3}$ European Commission and the United States Department of Transportation. (2010). Transatlantic airline alliances: Competitive issues and regulatory approaches. Retrieved from http://ec.europa.eu/competition/sectors/transport/reports/joint_alliance_report.pdf.
} 
There are three main air-alliances in Europe. They are described in the following Table 2:

Table $2^{4}$

Main Alliances

\begin{tabular}{llll}
\hline & Star alliance & One world & Sky team \\
\hline Members & 26 & 11 & 12 \\
Founding year & 1996 & 1999 & 2000 \\
$\begin{array}{l}\text { Founding } \\
\text { members }\end{array}$ & $\begin{array}{l}\text { Air Canada, Lufthansa, SAS, } \\
\text { Thai Airways, and United }\end{array}$ & $\begin{array}{l}\text { American Airlines, British } \\
\text { Airways, Cathay Pacific, }\end{array}$ & $\begin{array}{l}\text { Delta, Air France, Aeromexico, } \\
\text { Canadian Airlines, Quantas }\end{array}$ \\
$\begin{array}{l}\text { Market share of each } \\
\begin{array}{l}\text { alliance in transatlantic } \\
\text { market }\end{array}\end{array}$ & Airlines & $22.7 \%$ & $28.3 \%$ \\
\hline
\end{tabular}

Uncles and Goh analysed the impact of global alliances on customer loyalty (Uncles \& Goh, 2002). Their findings underline that business travellers "use a repertoire of airlines” (Uncles \& Goh, 2002). The commitment to a (global) alliance is $30 \%$ more agreed than to a single airline as is demonstrated in the following Figure 7 (Uncles \& Goh, 2002).

\section{Marketing and Forces}

As customer loyalty programmes are strongly connected with marketing strategies, Porter's five-force analysis is used to reveal potential issues for business success (Team Free Management eBooks [FME], 2013).

Potential entrants in the airline markets face limited incumbency, but if they do not cooperate with other airlines, they are only able to service a limited number of airports. There is also a huge capital requirement and the switching costs from airline alliances to a single carrier. Moreover, governmental policies may also build a strong barrier for new entrants. The bargaining power is also limited as few companies are concentrated in alliances and cooperation, also the risks of competitive rivalry are high, as big players are able to make price-games, reducing fares on the entrants destination routes. Buyer may decide to use other airlines, in case of lower fares but may tend to buy only single tickets. The bargaining power of suppliers is enormous, also each company needs raw materials, and therefore, if not connected with an alliance or cooperation, the prices may be quite high for a single airline. The competitive advantage can be achieved by yielding to smaller airports and hubs.

\begin{tabular}{|c|cccccc|c|}
\hline Commitment to: & $\begin{array}{c}\text { Strongly } \\
\text { Disagree }\end{array}$ & Disagree & Uncertain & Agree & $\begin{array}{c}\text { Strongly } \\
\text { Agree }\end{array}$ & $\begin{array}{c}\text { Mean } \\
\text { Response }\end{array}$ \\
\hline An Airline & 10 & 41 & 18 & 30 & 2 & 2.73 \\
A Global Alliance & 8 & 31 & 12 & 39 & 11 & 3.14 \\
\hline Average & 9 & 36 & 15 & 34 & 6 & 2.94 \\
\hline
\end{tabular}

Figure 7. Commitment to airlines and commitment to (global) alliances (percentage responding).

\footnotetext{
${ }^{4}$ European Commission and the United States Department of Transportation. (2010). Transatlantic airline alliances: Competitive issues and regulatory approaches. Retrieved from http://ec.europa.eu/competition/sectors/transport/reports/joint_alliance report.pdf.

${ }_{5}^{5}$ Uncles, M., \& Goh, K. (2002). Airline global alliances: What is their impact on customer loyalty? Retrieved from http://wwwdocs.fce.unsw.edu.au/marketing/Uncles_Goh01_6.pdf.
} 


\section{Loyalty Programmes}

“As an important component of firms' customer relationship management (CRM) strategy, loyalty programs aim to increase customer loyalty by rewarding customers for doing business with the firm” (Liu, 2007), stated by Liu and he underlined that the "long-term effects and the effectiveness of such programmes" had not been analysed yet. A loyalty programme is defined by Liu as "a programme that allows consumers to accumulate free rewards when they make repeated purchases with a firm” (Liu, 2007). As opposed to promotional single deals, customer loyalty programmes create a different customer lock-in than loyalty programs (Liu, 2007). At very broad view, customer loyalty can be seen as something that consumers may attract to special brands, better services, special product categories, and activities (Uncles, Dowling, \& Hammond, 2002). There is no universally agreed definition for consumer loyalty (Oliver, 1999). Oliver states that customer loyalty is developing in phases (Oliver, 1999).

Table 3 looks at the competitive interactions and their influence on airline profitability.

Table 3

Porter's Five-Forces Model for the Airline Industry ${ }^{6}$

\begin{tabular}{|c|c|c|c|c|c|c|}
\hline & & $\begin{array}{l}\text { Trends of subsititute } \\
\text { products or services } \\
\text { medium and rising }\end{array}$ & & & & \\
\hline & & \begin{tabular}{|l|} 
The number of customers \\
who can afford air travel is \\
increasing substantially, \\
mainly in emerging markets \\
\end{tabular} & & & & \\
\hline & & $\begin{array}{l}\text { Technology for } \\
\text { web-conferencing } \\
\text { improving }\end{array}$ & & & & \\
\hline & & $\begin{array}{l}\text { Fast trains are competitive } \\
\text { with airlines on short haul } \\
\text { due to security measures }\end{array}$ & & & & \\
\hline & & $\begin{array}{l}\text { Travel can be delayed, } \\
\text { limited or done without }\end{array}$ & & & & \\
\hline & & $\begin{array}{l}\text { Environmental issues } \\
\text { challenge air travel }\end{array}$ & & & & \\
\hline & & $\downarrow$ & & & & \\
\hline $\begin{array}{l}\text { Bargaining power of } \\
\text { suppliers: high }\end{array}$ & $\rightarrow$ & $\begin{array}{l}\begin{array}{l}\text { Rivalry among existing } \\
\text { competitors: high }\end{array} \\
\end{array}$ & $\leftarrow$ & $\begin{array}{l}\text { Bargaining power of } \\
\text { channels: high }\end{array}$ & $\leftarrow$ & $\begin{array}{l}\text { Bargaining power of } \\
\text { buyers: high }\end{array}$ \\
\hline $\begin{array}{l}\text { Powerful labour unions } \\
\text { especially when controlling } \\
\text { operations at network hubs }\end{array}$ & & $\begin{array}{l}\text { Growth has been rapid and } \\
\text { volatile }\end{array}$ & & $\begin{array}{l}\text { High concentration among } \\
\text { GDS (Global Distribution } \\
\text { System) and aggregator } \\
\text { websites }\end{array}$ & & Buyers are fragmented \\
\hline $\begin{array}{l}\text { Aircraft and engine } \\
\text { producers are both } \\
\text { concentrated oligopolies } \\
\end{array}$ & & Perishable product & & $\begin{array}{l}\text { Websites increase price } \\
\text { transparency }\end{array}$ & & $\begin{array}{l}\text { Air travel perceived as a } \\
\text { standardized product }\end{array}$ \\
\hline $\begin{array}{l}\text { Airports are local } \\
\text { monopolies with significant } \\
\text { power }\end{array}$ & & \begin{tabular}{|l|} 
Limited product \\
differentiation similar \\
company structures \\
\end{tabular} & & \begin{tabular}{|l|}
$\begin{array}{l}\text { Travel agents focus on the } \\
\text { interests of corporate buyers } \\
\text { to reduce travel costs }\end{array}$ \\
\end{tabular} & & $\begin{array}{l}\text { Low switching costs for } \\
\text { most customers }\end{array}$ \\
\hline $\begin{array}{l}\text { Airport services are } \\
\text { concentrated in a small } \\
\text { number of firms, but low } \\
\text { switching costs }\end{array}$ & & $\begin{array}{l}\text { High sunk costs per aircraft, } \\
\text { low marginal costs per } \\
\text { passenger }\end{array}$ & & & & $\begin{array}{l}\text { Price sensitive, because } \\
\text { travel is a meaningful } \\
\text { share of discretionary } \\
\text { spending }\end{array}$ \\
\hline
\end{tabular}

${ }^{6}$ IATA (International Air Transport Association). (2013). Profitability and the air transport value chain. Retrieved from https://www.iata.org/whatwedo/Documents/economics/profitability-and-the-air-transport-value\%20chain.pdf. 
Table 3 to be continued

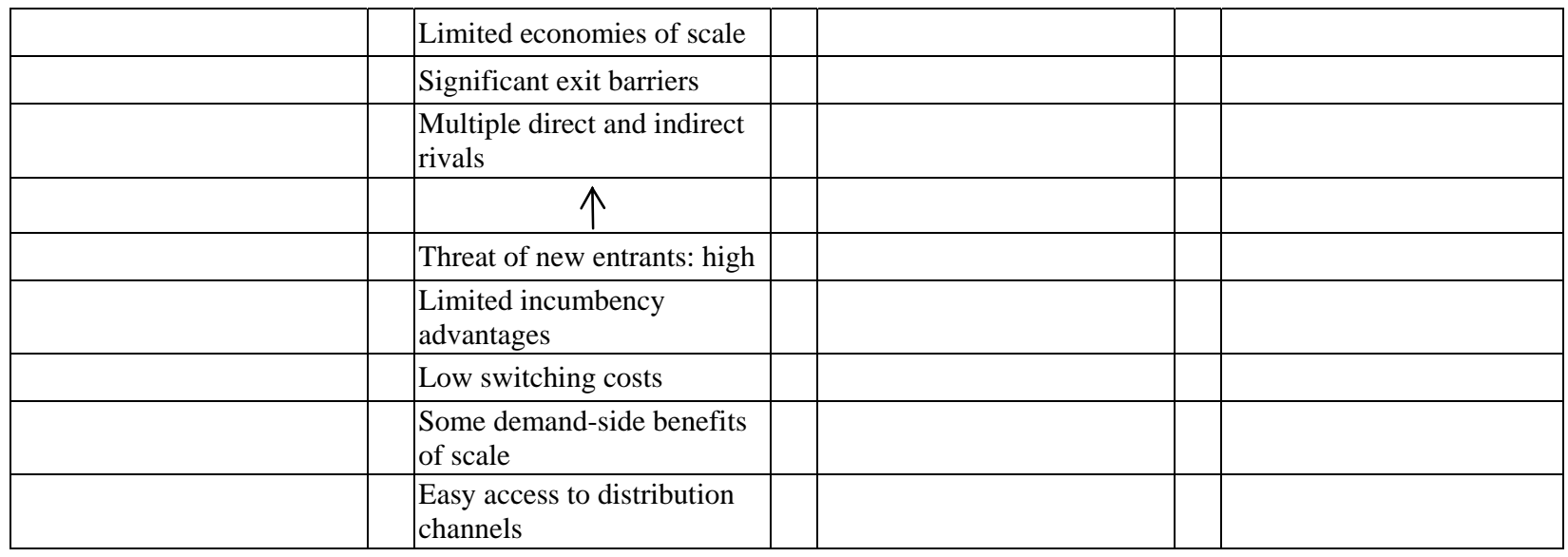

Figure 8 shows how customer loyalty develops in phases.

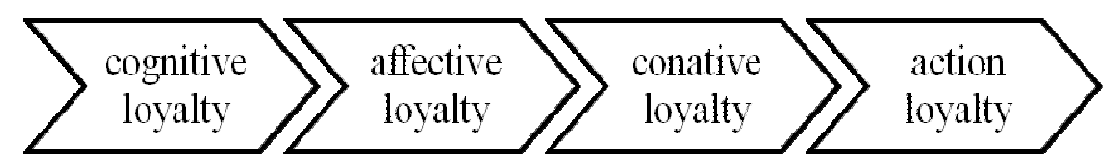

Figure 8 . The development of customer loyalty and its phases ${ }^{7}$.

The loyalty process starts with "cognitive loyalty" where the customer believes the product to be superior, followed by the second phase of "affective loyalty". The customer's satisfaction with the product or service is reiterated and confirms his/her expectations. The third phase "conative loyalty" is marked by high involvement and strong buying intentions and finally, the fourth phase, the "action loyalty", leads to action (Oliver, 1999). In a study based on interviews of 67 international airline managers and 1,203 international travellers (in most highly used airports in Europe) asked by mail, Martin-Consuegra, Molina, and Esteban (2006) revealed the following results (Martin-Consuegra et al., 2006):

Table 4 states the comparision between airlines and travellers opinions.

The overall sample population of international travellers consists of a higher representation of male respondents (Martin-Consuegra et al., 2006), “62\% of the respondents possessed college education, $47 \%$ of the respondents were employed either part time or fulltime, and the median age category (25-54 years group) represented $67 \%$ of the total sample" (Martin-Consuegra et al., 2006).

Due to the fact of international European airports, 70\% of the passengers interviewed were European, 28\% Americans and remaining from other countries (Martin-Consuegra et al., 2006). Only 3\% of the total respondents paid a first class fare, $74 \%$ of the remaining passengers purchased their airline tickets at a travel agency (Martin-Consuegra et al., 2006).

Based on these questions shown in the table above and using a 5-point Likert-type scale Martin-Consuegra et al. concluded that (Martin-Consuegra et al., 2006):

(1) The differences of expectations between the airline managers and the travellers are not extreme;

(2) While airlines focus on actions aimed at the differentiation of their products from their competitors', travellers centre their attention on economic benefits, such as lower prices in the services they are consuming;

${ }^{7}$ Oliver, R. L. (1999). Whence customer loyalty. Journal of Marketing, 63(Special Issue), 33-44. 
(3) The study highlights the need and enhances customer orientation within the airline sector (Martin-Consuegra et al., 2006).

Table 4

Comparision Between Airlines’ and Travellers' Opinions ${ }^{8}$

\begin{tabular}{llll}
\hline Ordered by gap & $\begin{array}{l}\text { Means of } \\
\text { travellers }\end{array}$ & $\begin{array}{l}\text { Means of } \\
\text { airlines }\end{array}$ & Gap \\
\hline Prestige and image of the company & 3.36 & 4.33 & -0.97 \\
Provide regular information on the range of services & 3.47 & 4.27 & -0.80 \\
Discounts and special offers & 4.23 & 3.44 & 0.79 \\
Adaptation of services to changes in the market & 3.60 & 4.36 & -0.76 \\
Good management and transparency of service & 4.15 & 4.52 & -0.37 \\
Offer advantages through loyalty programmes & 3.51 & 3.79 & -0.28 \\
Interest of the company in knowing the value & 4.10 & 4.35 & -0.25 \\
Easy access to information about the company & 3.92 & 4.11 & -0.19 \\
Offer clear information about the conditions & 4.17 & 4.35 & -0.18 \\
of service & 4.15 & 4.29 & -0.14 \\
Solutions to involuntary faults/problems & 3.85 & 3.71 & 0.14 \\
Adaptation of service to the specific needs of each customer & 4.55 & 4.42 & 0.13 \\
Efficient management of claims or complaints & 3.78 & 3.91 & -0.13 \\
Alliances with other airlines & 4.39 & 4.27 & 0.12 \\
Training and qualifications of personnel & 4.41 & 4.48 & -0.07 \\
Good deportment of personnel in contact with clients & 3.86 & 3.79 & 0.07 \\
Incorporate added travel benefits & 4.53 & 4.58 & -0.05 \\
Completion of conditions of service & 4.38 & 4.42 & -0.04 \\
Rapid response to claims or suggestions & 4.43 & 4.39 & 0.04 \\
Quality and price relationship of the service offered & & & \\
\hline
\end{tabular}

Following these steps, airlines should strongly focus on real customer needs. The key drivers to customer loyalty were analysed by Qvidian (2012), and he highlighted, that offering unique, valuable perspectives is the main driver for customer loyalty programmes (Qvidian, 2012). Uncles et al. (2002) argued that customer loyalty is a paradox and that it can primarily be seen as an attitude-based phenomenon, which can be influenced by CRM-activities (Uncles et al., 2002). The determinants of customer loyalty are: (1) service quality; (2) customer satisfaction; (3) trust; (4) commitment; (5) switching cost; (6) corporate image; (7) service recovery; (8) emotions; and (9) communication (Rai \& Srivastava, 2012).

However, there are complementary theories about customer loyalty. It is important to distinguish them in categories, especially, if brands are competing functionally similarly, like the airline industry (Uncles et al., 2002).

Figure 9 shows the categories of customer loyalty. In case of CBA (Customer Brand Acceptance), the advertised messages and benefits are fundamentally similar, like frequent flyer programmes. These facts lead to an acceptance based on accessibility and availability of a brand at the time of purchase (Uncles et al., 2002).

CBC (The Customer Brand Commitment) buyers are more oriented to invest in high identity products of life choices and they may be influenced by social standards, attitudes, and values (Kapferer, 1999). CBB (The Customer Brand Buying) is associated with low-level loyalty of customers and is an exception of CBA,

\footnotetext{
${ }^{8}$ Martin-Consuegra, D., Molina, A., \& Esteban, A. (2006). Customer orientation in the airline industry: A comparison between travelers and airlines. e-Review of Tourism Research (eRTR), 4(5), 108-118.
} 
therefore, their decision is strongly associated with availability, promotions, and weak attitudes (Uncles et al., 2002).

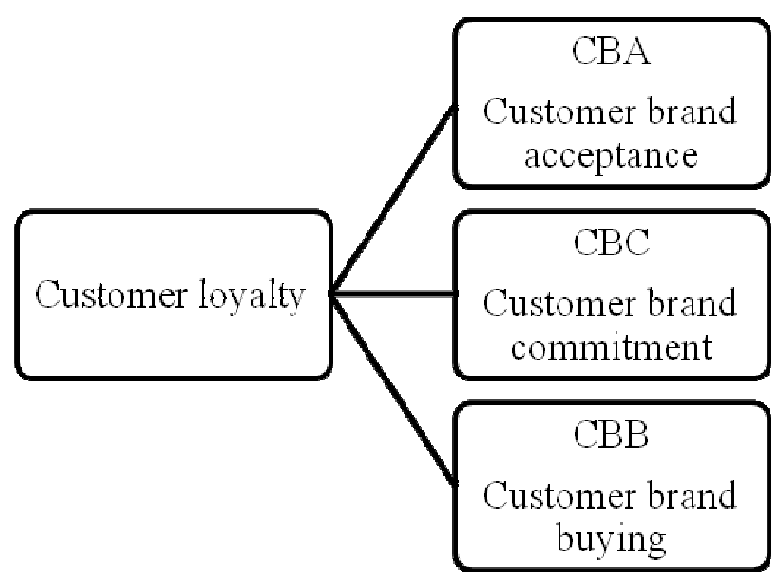

Figure 9. Categories of customer loyalty ${ }^{9}$.

\section{Conclusions and Prospects}

To sum up, the theoretical framework on customer loyalty, airlines and main drivers of loyalty programmes led to analysing service strategies, customer expectations, alliances, cooperation, and marketing forces and offered an intimate view on the pros and cons of customer loyalty programmes. The main drivers of customer loyalty programmes have been examined and future oriented consumer types were found.

The ongoing empirical process of investigation, based on online surveys and economic online research on customer loyalty programmes together with weighing positive and negative aspects combined with expert knowledge, is expected to give detailed information about the actual status of the airline industry.

\section{References}

Amadeus. (2012). From chaos to collaboration. Retrieved from http://www.amadeus.com/web/binaries/1333089277310/ blobheader=image/png

Amadeus. (2015). Future traveller tribes 2030: Understanding tommorow's traveller. Retrieved from http://www.amadeus. com/documents/future-traveller-tribes-2030/travel-infographic-future -traveller-tribes-2030.png

Birdsong, D. (2015). The airline customer experience: A disconnect between executives and travellers. Retrieved from http://airlines.iata.org/blog/2015/02/the-airline-customer-experience-a-disconnect-between-executives-and-travelers

Ciliberto, F., \& Williams, J. W. (2010). Limited access to airport facilities and market power in the airline industry. Journal of Law and Economics, 53, 467-495.

ECA (European Competition Authorities) Air Traffic Working Group. (2004). Mergers and alliances in civil aviation. Retrieved from http://ec.europa.eu/competition/publications/eca/report.pdf

ECA. (1995). Loyalty programmes in civil aviation-An overview of the competition issues concerning frequent flyer programmes, corporate discount schemes and travel agent commissions. Retrieved from http://www.cnmc.es/Portals/0/Ficheros/ Competencia/Instituciones/loyaltyprogrammes.pdf

European Commission and the United States Department of Transportation. (2010). Transatlantic airline alliances: Competitive issues and regulatory approaches. Retrieved from http://ec.europa.eu/competition/sectors/transport/reports/joint_alliance _report.pdf

Huthwaite International. (2015). Improving sales performance. Retrieved from http://www.huthwaiteinternational. com/south-africa

\footnotetext{
${ }^{9}$ Uncles M. D., Dowling, G. R., \& Hammond, K. (2002). Customer loyalty and customer loyalty programs. Retrieved from http://citeseerx.ist.psu.edu/viewdoc/download?doi=10.1.1.198.9635\&rep=rep1\&type=pdf.
} 
IATA (International Air Transport Association). (2013). Profitability and the air transport value chain. Retrieved from https://www.iata.org/whatwedo/Documents/economics/profitability-and-the-air-transport-value\%20chain.pdf

Kapferer, J.-N. (1999). Strategic brand management. Upper Saddle River, NJ: Prentice Hall.

Kotler, P., \& Armstrong, G. (2012). Principles of marketing (14th ed.). NJ: Pearson, Prentice Hall.

Liu, Y. (2007). The long-term impact of loyalty programs on consumer purchase behaviour and loyalty. Journal of Marketing, 71(4), 19-35.

Martin-Consuegra, D., Molina, A., \& Esteban, A. (2006). Customer orientation in the airline industry: A comparison between travelers and airlines. e-Review of Tourism Research (eRTR), 4(5), 108-118.

Morrison, S. A., \& Winston, C. (2005). What's wrong with the airline industry? Diagnosis and possible cures. Retrieved from http://www.brookings.edu/ /media/research/files/testimony/2005/9/28business-morrison/20050928winston.pdf

Oliver, R. L. (1999). Whence customer loyalty. Journal of Marketing, 63(Special Issue), 33-44.

Pi, W.-P., \& Huang, H.-H. (2011). Effects of promotion on relationship quality and customer loyalty in the airline industry: The relationship marketing approach. Retrieved from http://www.academicjournals.org/AJBM

Qvidian. (2012). CEB sales and marketing summit recap. Retrieved from http://www.qvidian.com/blog/ceb-sales-and -marketing-summit-recap

Rai, K. A., \& Srivastava, M. (2012). Customer loyalty attributes: A perspective. NMIMS Management Review, 22, 49-76.

Ranzinger, A. (2011). Praxiswissen kundenbindungsprogramme: Konzeption und operative umsetzung (Practial knowledge: Design and operational implementation). Wiesbaden, Germany: Gabler Verlag.

Strategy\&. (2015). 2015 aviation trends. Retrieved from http://www.strategyand.pwc.com /perspectives/2015- aviation-trends

Team FME (Free Management eBooks). (2013). Porter's five forces, strategy skills. Retrieved from http://www. free-management-ebooks.com/dldebk-pdf/ fme-five-forces-framework.pdf

The Chartered Institute of Marketing. (2015). Making membership work for you. Retrieved from http://www.camfoundation.com /PDF/Cost-of-customer-acquisition-vs-customer-retention.pdf

Uncles, M. D., Dowling, G. R., \& Hammond, K. (2002). Customer loyalty and customer loyalty programs. Retrieved from http://citeseerx.ist.psu.edu/viewdoc/download?doi=10.1.1.198.9635\&rep=rep1\&type=pdf

Uncles, M., \& Goh, K. (2002). Airline global alliances: What is their impact on customer loyalty? Retrieved from http://wwwdocs.fce.unsw.edu.au/marketing/Uncles_Goh01_6.pdf

Wessels, D. (2006). Consumer loyalty in the airline industry. Retrieved from http://finance.wharton.upenn.edu/ wessels/courses/valuation/Sample\%20Solution\%20-\%20Marketing.pdf 
Appendix

CBA

Customer Brand Acceptance

$\mathrm{CBB}$

The Customer Brand Buying

$\mathrm{CBC}$

The Customer Brand Commitment

CDS

Corporate Discount Schemes

CSR

Corporate Social Responsibility

CTR

Click-Through Rate (Google)

EASA

European Aviation Safety Agency

ECA

European Competition Authorities

FFPs

IATA

ICAO

IMF

Frequent Flyer Programmes

International Air Transport Association

LCC

International Civil Aviation Organization

PCI

International Monetary Fund

Low Cost Carrier

PPC

Psychological Commitment Instrument

Pay-Per-Click (Google)

SERP

Search Engine Results Page (Google) 